\title{
Comparision of Performance and Emission Test Using Biodiesel from Simarouba and Waste Cooking Oil in CI Engine
}

\author{
M. D. Harlapur ${ }^{1}$, Siddesh Bevinahalli ${ }^{2}$, Manjunath B. Sasi ${ }^{3}$ \\ ${ }^{1}$ HOD Department of Mechanical Engg, Rural Engg College Hulkoti \\ ${ }^{2}$ Assistant Professor, Department of Mechanical Engg, Rural Engg College Hulkoti \\ ${ }^{3}$ Student, Department of Mechanical Engg, Rural Engg College Hulkoti
}

\begin{abstract}
The depletion of world petroleum reserves and increased environmental concern have stimulated the search of alternative fuel which is to be environment friendly. Bio-fuels have the potential to become alternative fuel for fossil fuels. Biodiesel is renewable, reliable, biodegradable and regarded as a clean alternative fuel to reduce exhaust emissions. In recent years, much research has been carried to find suitable alternative fuel to petroleum products. In the present investigation experimental work has been carried out to analyze the performance and emissions characteristics of a single cylinder compression ignition DI engine fuelled with the blends of mineral diesel and biodiesel. The simarouba biodiesel is considered as alternative fuels to diesel. A large amount of tree borne oils and fats are available for biodiesel production in developing and under develop countries. Simarouba glauca oil is one of these oils. The utilization of liquid fuels such as biodiesel produced from waste cooking oil by transesterification process represents one of the most promising options for the use of conventional fossil fuels. However, as the biodiesel is produced from vegetable oils and animal fats, there are concerns that biodiesel feedstock may compete with food supply in the long-term. Hence, the recent focus rely on using waste cooking oil as the substantial feed stocks for biodiesel production.
\end{abstract}

Keywords: Diesel, Biodiesel, Simarouba biodiesel (SOME), Waste cooking oil biodiesel (WCOME), transesterification, Performance, Emission Charecteristics

\section{Introduction}

Biofuels are a serious option to compete with oil in the transport system compared to other technologies such as hydrogen, because biofuel technologies are already well developed and available in many countries. Bioethanol and biodiesel can be mixed with the petroleum products (gasoline and diesel) they are substituting for and can be burned in traditional combustion engines with blends containing up to 10 per cent biofuels without the need for engine modifications.

India is a diesel-deficit nation and demand has far out striped supply. India's diesel production will not be able to keep pace with the rapidly growing demand. Government's pricing policy now allows oil companies to decide prices. Diesel is not much cheaper than petrol any more. Diesel demand in the country is growing at an annual rate of $8 \%$. At this rate India will need a brand new 9 Million Tons per year refinery every year. The automobiles industry has estimated that the share of diesel vehicles, in overall vehicle sales has crossed the $40 \%$ mark. The price of fuels is now going to be in line with price of crude oil. Hence the Petrol and Diesel prices are now in line with international price levels, which makes biofuel economically attractive.

India's biodiesel processing capacity is estimated at 600,000 tons per year. The government owned Oil Marketing companies have now floated a tender again to buy 840 million liters of Biodiesel. However there are few interested suppliers. They prefer to export, rather than selling in India.
Biofuel development and use is a complex issue because there are many biofuel options which are available. Biofuels, such as ethanol and biodiesel, are currently produced from the products of conventional food crops such as the starch, sugar and oil feedstocks from crops that include wheat, maize, sugar cane, palm oil and oilseed rape. Some researchers fear that a major switch to biofuels from such crops would create a direct competition with their use for food and animal feed, and claim that in some parts of the world the economic consequences are already visible, other researchers look at the land available and the enormous areas of idle and abandoned land and claim that there is room for a large proportion of biofuel also from conventional crops. $[5,7,9,10]$

\section{Material and Methodology}

\section{A. Common Process of Biodiesel Production:}

Biodiesel derived from biological resources is a renewable fuel, which has drawn more and more attention recently. A fatty acid methyl ester is the chemical composition of biodiesel. Transesterification is widely used for the transformation of triglyceride into fatty acid methyl ester. The manufacturing process is based on the transesterification of triglycerides by alcohols to fatty acid methyl esters, with glycerol as a byproduct. The base catalyzed production of biodiesel generally has the following processes.

Transesterification: This is most commonly used process in production of biodiesel. It is most commonly used and important method to reduce the viscosity of vegetable oils. 


\section{International Journal of Science and Research (IJSR) \\ ISSN (Online): 2319-7064 \\ Index Copernicus Value (2013): 6.14 | Impact Factor (2015): 6.39}

In this process triglyceride reacts with three molecules of alcohol in the presence of a catalyst producing a mixture of fatty acids, alkyl ester and glycerol. The process of removal of all the glycerol and the fatty acids from the vegetable oil in the presence of a catalyst is called esterification.

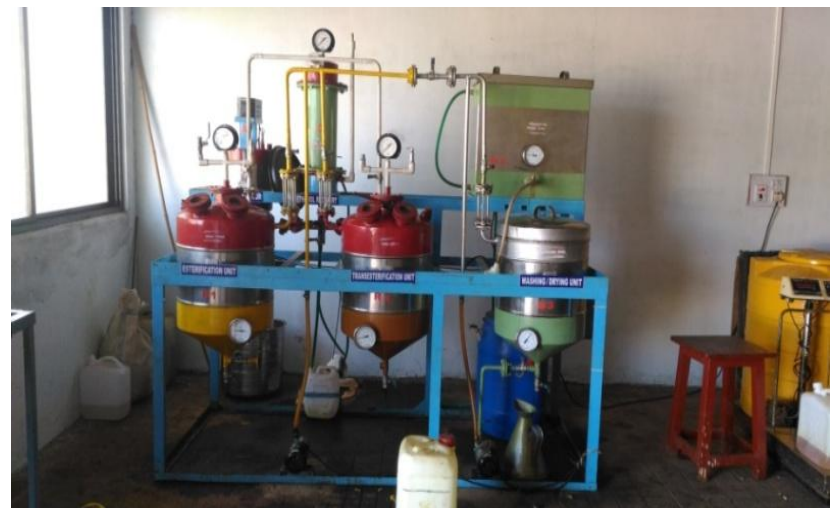

Figure 1: Transesterification

B. Properties of biodiesel

\begin{tabular}{|c|c|c|c|}
\hline Properties & diesel & SOME B20 & COME B20 \\
\hline Flash point $\left({ }^{0} \mathrm{c}\right)$ & 57 & 60 & 59 \\
\hline Fire point $\left({ }^{0} \mathrm{c}\right)$ & 63 & 64 & 62 \\
\hline Density $\left(\mathrm{Kg} / \mathrm{m}^{3}\right)$ & 830 & 837.4 & 838.2 \\
\hline Viscosity $(\mathrm{Cst})$ & 2.9 & 3.28 & 3.24 \\
\hline $\mathrm{CV}(\mathrm{KJ} / \mathrm{Kg})$ & 42500 & 41960 & 41500 \\
\hline
\end{tabular}

\subsection{Experimental Setup}

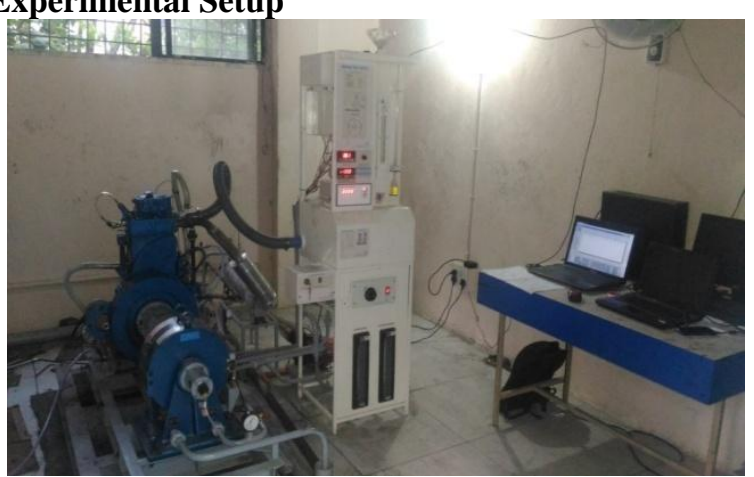

Figure 2: Engine Setup

Table 2: Engine Specification

\begin{tabular}{|c|c|}
\hline Product & $\begin{array}{c}\text { VCR Engine test setup 1 cylinder, 4 stroke, } \\
\text { Diesel (Comp.) }\end{array}$ \\
\hline Engine & $\begin{array}{c}\text { Make Kirloskar, Type 1 cyl. 4 stroke Diesel, } \\
\text { water cooled, power 3.5kW at 1500rpm, } \\
\text { stroke 110mm, and bore 87.5mm. 661 cc, } \\
\text { CR17.5, Modified to VCR engine CR 12 to } \\
18 . \text { with electric start arrangement, battery } \\
\text { and charger }\end{array}$ \\
\hline Dynamometer & Type eddy current, water cooled, \\
\hline Load sensor & Load cell, type strain gauge, range 0-50 Kg \\
\hline Compression ratio & $17.5: 1$ \\
\hline
\end{tabular}

\section{Result and Discussion}

Comparison of Biodiesels

\subsection{LOAD VS BTE}

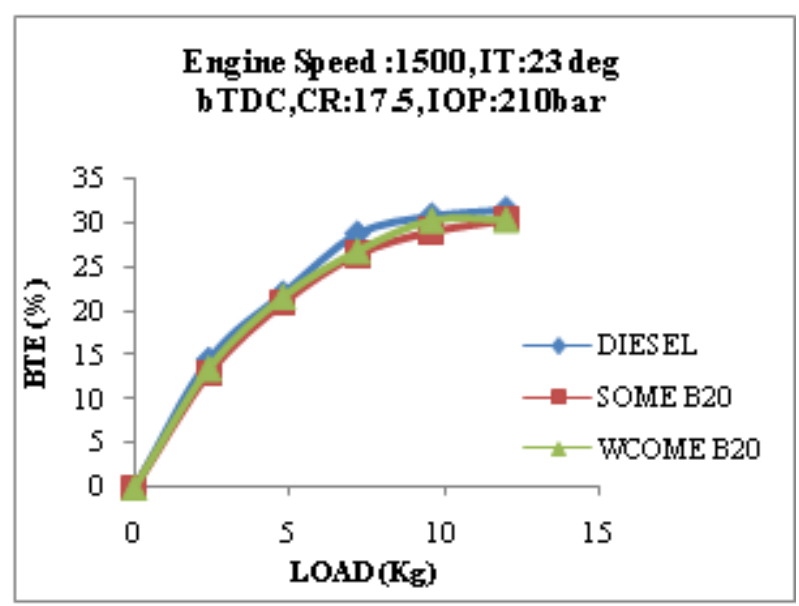

\subsection{LOAD VS SFC}

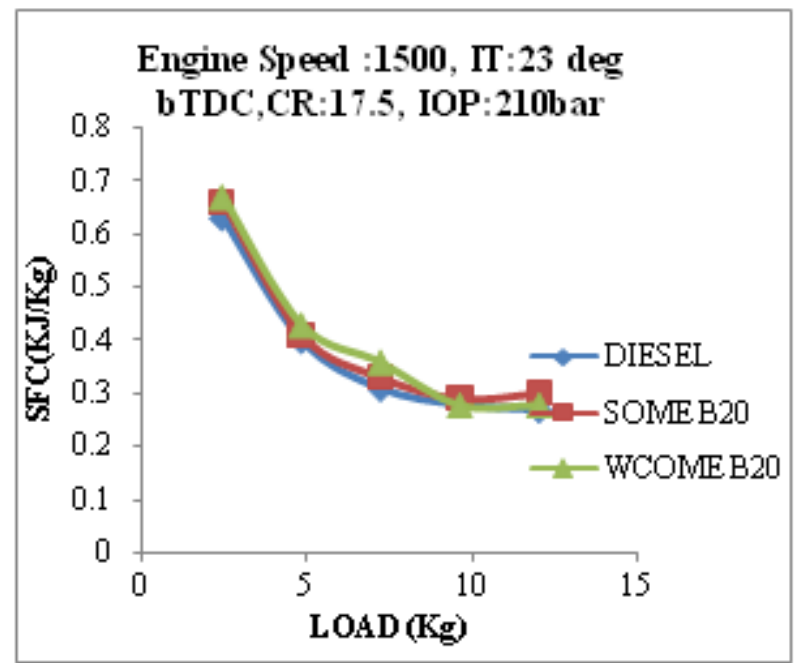

\subsection{LOAD VS VOL Eff}

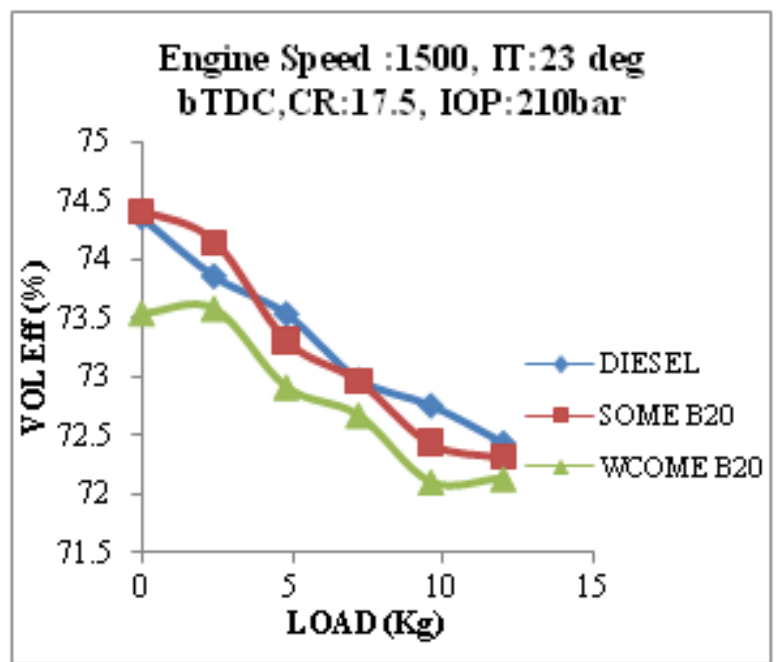

Volume 5 Issue 6, June 2016 www.ijsr.net 


\subsection{LOAD VS HC}

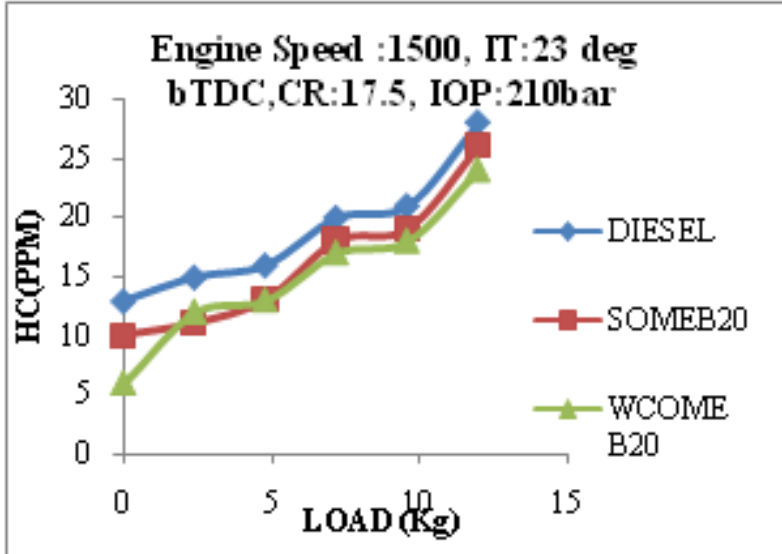

\subsection{LOAD VS NOx}

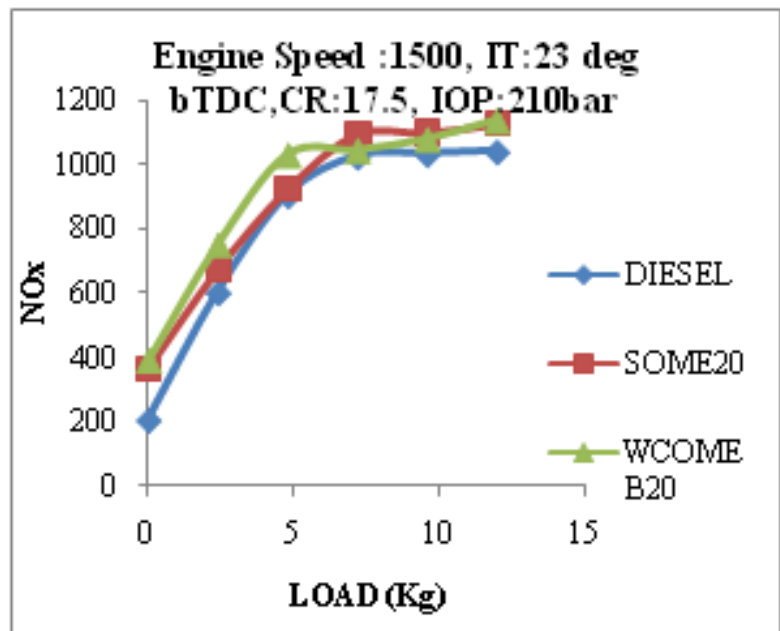

\subsection{LOAD VS $\mathrm{CO}_{2}$}

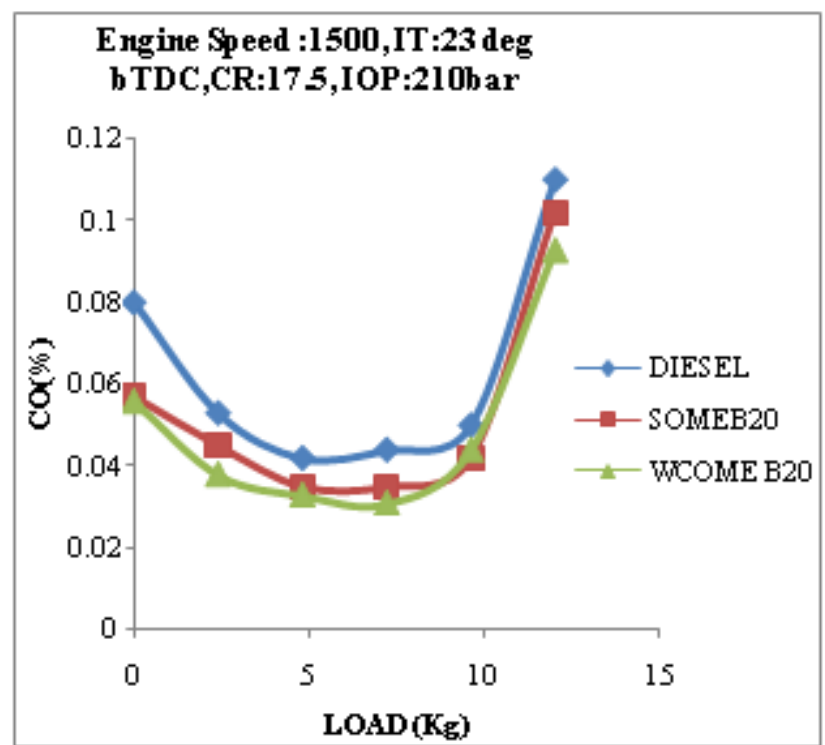

\subsection{LOAD VS $\mathrm{CO}_{2}$}

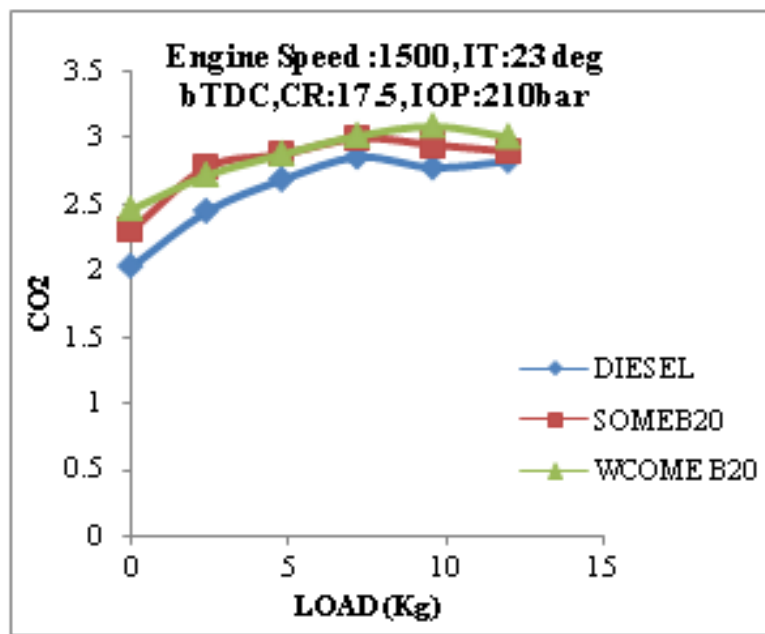

\subsection{LOAD VS $\mathrm{O}_{2}$}

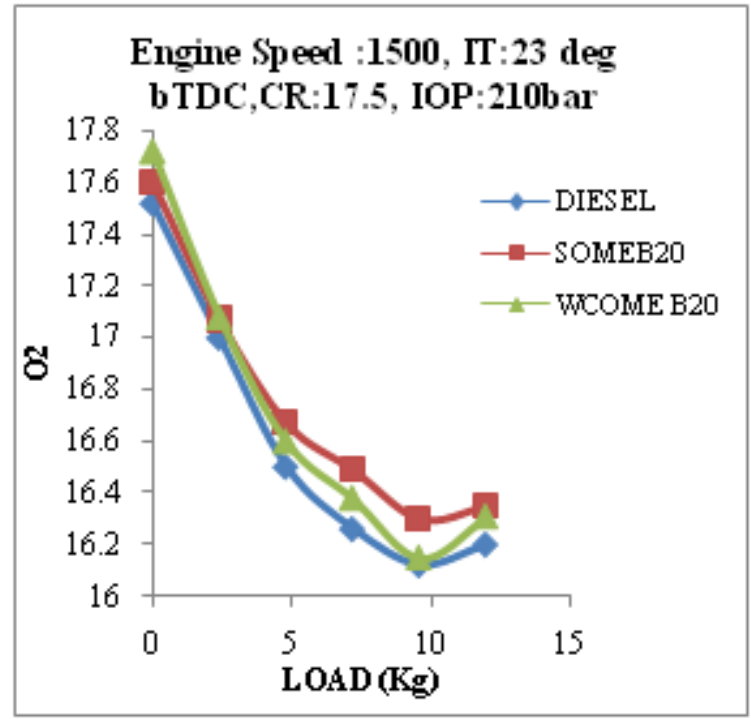

\section{Conclusion}

1) Performance, combustion and emission characteristics of WCOME B20 blend are better than SOME B20 blend. And efficiency of WCOMEB20 is well compare with the diesel. The maximum brake thermal efficiency of WCOME B20, SOME B20 and DIESEL are respectively $31.67 \%, 30.95 \%$ and $30 \%$.

2) The BSFC decreased with an increase in engine load. For biodiesel and its blends the BSFC are higher than that of diesel fuel. The BSFC values for biodiesels, SOME B20 and WCOME B20 blends are 0.28 and 0.30 respectively, which is higher than diesel fuel.

3) The NOx emission is higher than diesel fuel for all modes of test fuels. This is due to higher oxygen content of biodiesel, which would result in better combustion and maximum cylinder temperature. The maximum value of NOx emission is $9 \%$ of wcome and $8 \%$ of some at full load conditions, which is higher than diesel fuel.

4) For biodiesel and its blends, it was found that $\mathrm{CO}$ and $\mathrm{HC}$ emissions were lower than that of pure diesel. The lowest $\mathrm{CO}$ and $\mathrm{HC}$ emissions were obtained for neat biodiesel (B100). The maximum reduction in $\mathrm{CO}$ and $\mathrm{HC}$

Volume 5 Issue 6, June 2016 www.ijsr.net 


\section{International Journal of Science and Research (IJSR) \\ ISSN (Online): 2319-7064}

Index Copernicus Value (2013): 6.14 | Impact Factor (2015): 6.39

emission with neat biodiesel and at full load are $16 \%$ and $20 \%$ respectively which is lower than diesel fuel.

5) On the whole, the methyl esters of Simarouba biodiesel and waste cooking biodiesel and its blends can be used as an alternative fuel in diesel engines without any engine modifications. It gives lower $\mathrm{HC}, \mathrm{CO}$ emission when compared with the diesel fuel. But the addition of higher percentage of biodiesel blend with diesel fuel which decreases brake thermal efficiency and increases specific fuel consumption.

6) The best blending ratio is 20\% SOME and $20 \%$ WCOME which gives the best performance which is closer compared to diesel fuel and less increase in the NOx emissions as compared with other SOME and WCOME blends.

7) It is found that $\mathrm{CO} 2$ emissions are more for simarouba and wastecooking biodiesel than that of diesel. Higher $\mathrm{CO} 2$ emissions reduce harmful $\mathrm{CO}$ emissions. The percentage reduction in $\mathrm{HC}$ emissions for simarouba and waste cooking biodiesel is about $60 \%$ as compared to that of Diesel. Due to higher NOx emissions with pure Simarouba and waste cooking biodiesel, suitable blends can become a striking balance between NOx emissions on one end and all other emissions along with performance on the other hand.

8) Taking the analysis of all above graphs we are finding that ,SOME and WCOME both the biodiesels are best alternative fuels for CI engine .By comparing both the biodiesels performance and emissions characteristics we are concluded that WCOME biodiesel is gives a best performance with compare to SOME biodiesel.

\section{References}

[1] B.K.Venkanna, C.Venkataramana Reddy. Performance, emission and combustion characteristics of direct injection diesel engine running on calophyllum inophyllum linn oil (honne oil) Int J Agric \& Biol Eng Vol. 4 March, 2011.

[2] Ricky Priambodo et al.energy procedia 75(2015) 8491. Novel Technology for Bio-diesel Production from Cooking and Waste Cooking Oil by Microwave Irradiation.

[3] Sharun Mendonca et al, International Journal of Scientific and Research Publications, Volume 3, Issue 4, April 20131 ISSN 2250-3153. Influence of Injection Timing on Performance and Emission Characteristics of SimaroubaBiodiesel Engine

[4] Mishra S.R et al. Research Journal of Chemical Sciences Vol. 2(5), 66-71, May (2012) . Production of Bio-diesel (Methyl Ester) from Simarouba Glauca Oil.

[5] Shailesh Golabhanvi et al, International Journal of Emerging Trends in Engineering and Development Issue 4, Vol.3 (May 2014) Available online on .performance,emissionand combustion characteristics of a single cylinder engine operating on simarouba biodiesel and doesel blends.

[6] Amaramma et al, www.ijird.com June, 2014 Vol 3 Issue 6, ISSN 2278 - 0211, Extraction of Simarouba Biodiesel and Experimental Investigation of its Suitability as Fuel for CI Engine

[7] Somashetty $S$ S, et al. International Journal of Engineering and Technical Research (IJETR) ISSN:
2321-0869, Volume-3, Issue-5, May 2015. Production of Biodiesel from Simarouba Seeds and Performance Test on Single Cylinder Compression Ignition Engine with Variable Injection Pressure.

[8] Alemayehu Gashaw et al, International Journal of Renewable and Sustainable Energy2014; 3(5): 9298Published online September 10, 2014 (http://www.sciencepublishinggroup.com/j/ijrse) doi: 10.11648/j.ijrse.20140305.12 ISSN: 2326-9715 (Print); ISSN: 2326-9723. Production of biodiesel from waste cooking oil and factors affecting its formation: A review.

[9] [2] A ABU-JRAI, J. A. YAMIN, A. H. ALMUHTASEB, AND M. A. HARARAH, "Combustion characteristics and engine emissions of a diesel engine fueled with diesel and treated waste cooking oil blends", Chemical Engineering Journal, Vol.172, pp.129-13, 2011.

[10] [5] Y. DI, C. S. CHEUNG, AND Z. HUANG, "Experimental investigation on regulated emissions of a diesel engine fueled with ultra- low sulfur diesel fuel blended with biodiesel from waste cooking oil", Science of The total Environment Journal, Vol.407, pp.835-846, 2009. 